\title{
Sustainability of different production systems papaya (Carica papaya L.) and sorghum (Sorghum bicolor [L.] Moench) in the semi-arid region
}

\author{
Erialdo O. Feitosa ${ }^{1 *}$, Fernando B. Lopes ${ }^{1}$, Eunice M. Andrade', Helba A.Q. Palácio², \\ and Francisco M.L. Bezerra ${ }^{1}$ \\ 'Universidade Federal do Ceará, Departamento de Engenharia Agrícola, Av. Mister Hull s/n, Fortaleza, Ceará, Brasil. \\ "Corresponding author (erialdofeitosa5@gmail.com). \\ ${ }^{2}$ Instituto Federal de Educação, Ciência e Tecnologia do Ceará, Caixa-postal: 38, Iguatu, Ceará, Brasil.
}

Received: 17 July 2018; Accepted: 26 November 2018; doi:10.4067/S0718-58392019000100114

\begin{abstract}
Agricultural production in the semi-arid region is critically important for ensuring food security and agricultural development in world. However, due to the environmental impact generated by agricultural activity, and the challenge of producing food for a growing demand, agriculture is dependent on a constant flow of non-renewable environmental and economic resources. The aim of this study was to quantify the sustainability of different agricultural production systems papaya (Carica papaya L.) and sorghum (Sorghum bicolor [L.] Moench) in the semi-arid region using emergy analysis. The research was carried out in the Curupati Irrigated Perimeter, located in the municipality of Jaguaribara, Ceará (CE), Brazil, corresponding to the cultivation of the irrigated papaya and in the Lagoa Grande settlement, in the Chapada do Apodi, municipality of Tabuleiro do Norte, $\mathrm{CE}$, referring to sorghum cultivation in the rainfed. The rainfed production system had an emergy value of $1.06 \mathrm{E}+16 \mathrm{seJ} \mathrm{ha}^{-1} \mathrm{yr}^{-1}$, and was lower than in the irrigated system $1.69 \mathrm{E}+17 \mathrm{seJ} \mathrm{ha}^{-1} \mathrm{yr}^{-1}$. The following values were obtained for the emergy indicators in the irrigated system: emergy yield ratio $(\mathrm{EYR})=1.51$; renewability $(\mathrm{R} \%)=74.29 \%$; environmental load ratio $(\mathrm{ELR})=0.35$, and emergy sustainability index $(\mathrm{ESI})=4.37$. Where as in the rainfed system, the $\mathrm{EYR}=1.13 ; \mathrm{R} \%=83.81 \%$; $\mathrm{ELR}=0.20$ and $\mathrm{ESI}=5.86$. The system of production under the rainfed regime therefore displayed better economic, social and environmental performance in relation to the irrigated production system. Both of the studied production systems contributed to the economic growth of the semi-arid region, with low environmental loads.
\end{abstract}

Key words: Emergy, irrigated agriculture, rainfed regime, sustainable development.

\section{INTRODUCTION}

Currently, irrigated agriculture is an important activity, since there is continuous growth in the demand for food, due to the increase in population and the search for a better quality of life. According to the Food and Agriculture Organization of the United Nations (FAO), in the next 25 years, $80 \%$ of the food needed by the human population will be supplied by irrigated crops (FAO, 2012). In the northeast of Brazil, this agricultural model is important due to significant market growth, giving greater production and higher yields for the sector (Lopes et al., 2011).

Rainfed agriculture is of critical importance, due to its growth and its implications for the food security of a significant number of people living in the semi-arid region of northeastern Brazil. Nasuti et al. (2013), when conducting research in semi-arid regions of the northeast of Brazil, found that around $60 \%$ of farmers adopted the rainfed system. According to the FAO, this production model accounts for approximately $80 \%$ of the world's arable land and $60 \%$ of the area under 
food production (FAO, 2012). In India, approximately $56 \%$ of all agricultural land is cultivated under a rainfed regime, contributing with $40 \%$ of the food production of the country (Venkateswarlu and Prasad, 2012).

The sharp increase in global food demand over the coming decades will depend on both irrigated and rainfed production systems, at the same time that the development of irrigated and rainfed agriculture will face the risk of water scarcity in addition to environmental problems (Chen et al., 2011).

In the search for greater productivity, producers have increased the use of technological inputs, such as the intensive use of machines, fertilizers, pesticides, etc., by which they raise energy flows through the agroecosystem to unsustainable levels. These environmental costs, or the externalities of such environmental impacts from agricultural practices, are generally not measured, and often do not influence the farmers' choice regarding agricultural production practices (Tilman et al., 2002).

Determining the sustainability of production systems is complex. However, the vast majority of methodologies used in evaluating these systems are based on input and output flows, taking only the economic factor into account (Palácio et al., 2012). With the aim of presenting a methodology that would evaluate systems in an integrated way, Odum (1996) developed the emergy methodology, which uses indicators capable of characterizing and comparing different production systems from an economic, social and environmental point of view.

The principal indicators that make up this method of evaluating the sustainability of production models are: solar transformity (Tr), emergy yield ratio (EYR), renewability (R\%), emergy investment ratio (EIR), environmental load ratio (ELR), emergy sustainability index (ESI) and emergy exchange rate (EER), as well as total emergy (Y) (Odum, 1996; Brown and Ulgiati, 2004; Ortega et al., 2010).

Based on these indicators, production models can be evaluated to determine which production system has the best economic, environmental and social performance. Many studies that use this methodology have been undertaken worldwide; however, there are few studies on the emergy analysis of agricultural production systems in semi-arid regions.

Barros et al. (2009) analyzed emergy and economic performance in systems of banana cultivation in Guadeloupe in the French West Indies. Wang et al. (2014) evaluated the emergy of different grain-production systems in northern China. Yi and Xiang (2016) analyzed the emergy of a rice production system in Hunan Province, China. Giannetti et al. (2011) recorded emergy flows in a coffee production system in the Brazilian Cerrado. Cavalett and Ortega (2009), in a study on the emergy, evaluated nutrient balance and economic evaluation of soybean production in Brazil.

The aim of this study therefore, was to evaluate, based on indicators of the emergy methodology, the economic, environmental and social performance of a production system for irrigated papaya (Carica papaya L.) and a production system for sorghum (Sorghum bicolor [L.] Moench) under a rainfed regime, both in the semi-arid region of Brazil.

\section{MATERIALS AND METHODS}

\section{Location of the production systems}

The irrigated agricultural production system is inserted in the Curupati Irrigated Perimeter, located in the town of Jaguaribara $\left(5^{\circ} 40^{\prime} \mathrm{S}, 38^{\circ} 40^{\prime} \mathrm{W} ; 150 \mathrm{~m}\right.$ a.s.1.), State of Ceará, Brazil. The rainfed production system is located in the Lagoa Grande settlement, in the Chapada do Apodi ( $5^{\circ} 20^{\prime} \mathrm{S}, 38^{\circ} 0^{\prime} \mathrm{W}$; $145 \mathrm{~m}$ a.s.l.) Ceará. Both production systems are located in the semi-arid region of Brazil (Figure 1).

\section{Characterization of soil and climate}

According to the Köppen classification, the climate in the region of the irrigated perimeter is type BSw'h', hot semi-arid, with average monthly temperatures above $18{ }^{\circ} \mathrm{C}$. The average annual rainfall is $810 \mathrm{~mm}$, with $80 \%$ of total precipitation from January to April. The predominant soils are Neosols, Luvisols, and Argisols (Entisols, Alfisols, Ultisols). In the region of the rainfed production system, climate is type BSw'h', with average monthly temperatures above $18^{\circ} \mathrm{C}$. The average annual rainfall is $790 \mathrm{~mm}$, with maximum rainfall concentrated from February to April. The soil is classified as a eutrophic red yellow Cambisol (Inceptisols). Other climate characteristics for the regions of the irrigated and rainfed production systems are shown in Table 1, comprising mean values of a historical series from 2000 to 2017. 
Figure 1. Location of the semi-arid region of Brazil and the irrigated and rainfed agricultural systems.

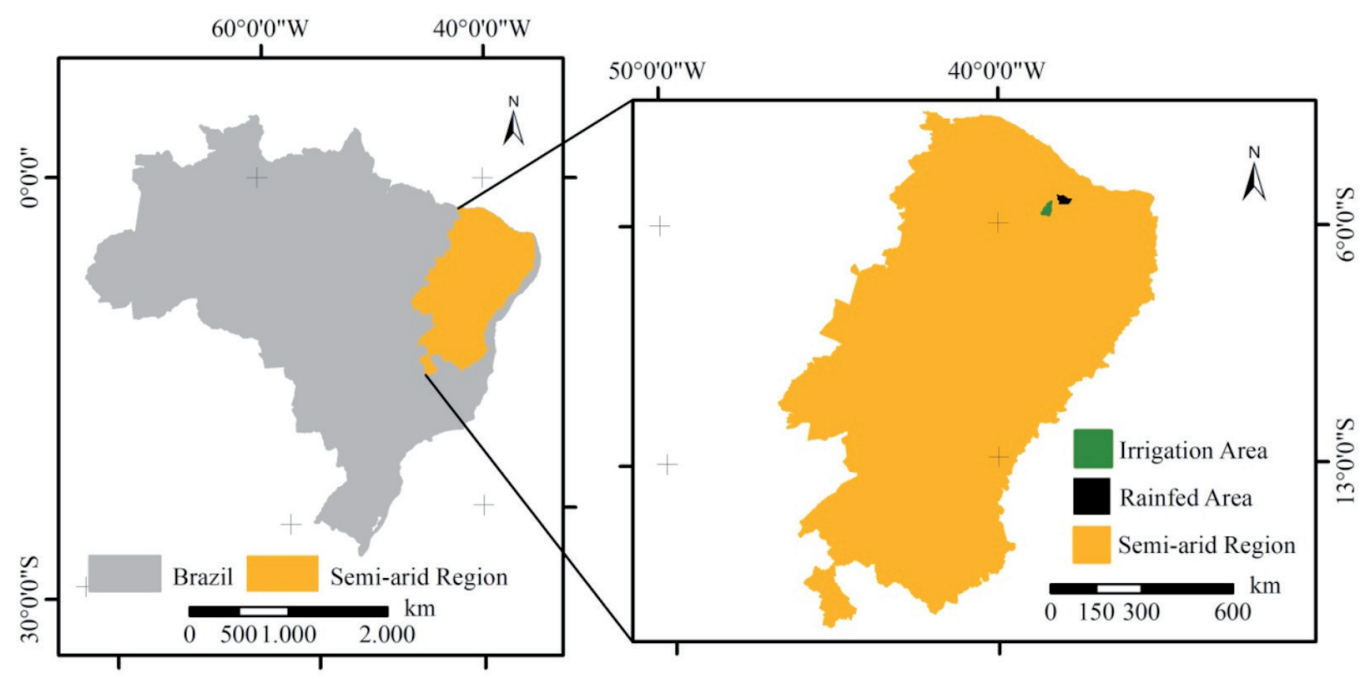

Table 1. Climate characteristics for the regions of irrigated and rainfed production systems.

\begin{tabular}{lrr}
\hline Parameter & Irrigated & Rainfed \\
\hline Average annual insolation, $\mathrm{h} \mathrm{yr}^{-1}$ & 2935.7 & 3068.5 \\
Average annual potential evaporation, $\mathrm{mm} \mathrm{yr}^{-1}$ & 1810.3 & 1798.8 \\
Average annual maximum temperature, ${ }^{\circ} \mathrm{C}$ & 33.6 & 33.5 \\
Average annual temperature, ${ }^{\circ} \mathrm{C}$ & 27.3 & 27.7 \\
Average annual minimum temperature, ${ }^{\circ} \mathrm{C}$ & 22.9 & 23.3 \\
Average annual relative humidity, $\%$ & 66.4 & 71.5 \\
Average annual wind speed, $\mathrm{m} \mathrm{s}^{-1}$ & 3.7 & 3.6 \\
\hline
\end{tabular}

Source: INMET (2017).

\section{Description of production systems}

The Curupati irrigated perimeter comprises a total area of 189 ha, in which the irrigated production model included 63 producers who cultivated irrigated papaya (Carica papaya L.) under a drip-irrigation system in an area of 94.5 ha divided into 18 lots. The water source for the irrigated perimeter was the Castanhão reservoir, delivered by a floating motor pump with a power of $500 \mathrm{hp}$ and flow rate of $0.33 \mathrm{~m}^{3} \mathrm{~s}^{-1}$, whose purpose was to feed the distribution channel. Another set consisting of four motor pumps with a power of $75 \mathrm{hp}$, pumped the water from the canal to the irrigated lots. The papaya crop was planted in rows spaced $4 \mathrm{~m}$ apart, with $1.8 \mathrm{~m}$ between plants; the spacing between drippers was $0.4 \mathrm{~m}$ at a flow rate of $2.0 \mathrm{~L} \mathrm{~h}^{-1}$.

The rainfed production system consisted of an agricultural field of 250 ha, inhabited by 92 farming families; however, only 12 farmers who had planted grain sorghum (Sorghum bicolor [L.] Moench) in an area of 138 ha were monitored. The first operation carried out by the producers was the lodging and desiccation of the existing vegetation in the area. The herbicide used was glyphosate at a dose of $2.5 \mathrm{~L} \mathrm{ha}^{-1}$. Was applied with a mechanized sprayer (Jacto, Pompeia, São Paulo, Brazil), driven by a 75-hp tractor (model 296, Massey Ferguson, Duluth, Georgia, USA).

The second operation was planting, using seed of the BR 304 sorghum hybrid. The operation was carried out under a no-till system using a seeder (model SP Light 3000, Baldan, Matao, Sao Paulo, Brazil), driven by a $75 \mathrm{hp}$ tractor (model 785, Valtra, Duluth, Georgia, USA). Seeding was carried out $8 \mathrm{~d}$ after applying the herbicide, at a depth of 5 to $6 \mathrm{~cm}$, with 6 to 7 seeds per linear meter, at a spacing between rows of $0.45 \mathrm{~m}$, giving a population of around 133332 to 155554 plants $\mathrm{ha}^{-1}$. The final operation was harvesting, also carried out mechanically by means of a harvester (model 7130, CASE IH, Racine, Wisconsin, USA). 


\section{Emergy analysis}

To enable an economic, social and environmental evaluation of the different production systems, emergy methodology based on the work of Odum (1996), Brown and Ulgiati (2004), and Ortega et al. (2010) was used. The first step in the emergy analysis was to identify the components of the two production systems, i.e. to determine the inputs and outputs. A systemic diagram of the systems was then developed, in which all the components and energy flows of the irrigated and rainfed production models were identified.

The input and output flows of the production systems were quantified using information from the farmers, data from the literature, field measurements, input and product sampling, as well as the tracking and monitoring of the Curupati Irrigated Perimeter and the rainfed area.

After defining the input and output variables of the agricultural production models, each input flow in the systemic diagram was converted into a calculation line of the emergy-evaluation matrix. For the matrix, all the flows of energy, mass and monetary value that were considered in the process were converted to a common basic unit, solar energy equivalent joules (seJ), using emergy transformations taken from the literature.

For determined economic transformity $\left(\mathrm{seJ} \${ }^{-1}\right.$ or $\left.\mathrm{Em} \$\right)$ was the equation: $\mathrm{Em} \$=\{[248.0+878.16 \times \mathrm{EXP}(-1 \times((\mathrm{yr}$ - 1981)/9.49)) $] / 100\} \times 1012 \times 1.68$ (Agostinho et al., 2008). The estimated value of the Emdollar (Em\$) was 4.54E+12 seJ USD ${ }^{-1}$ for 2016. This value was corrected by a factor of 1.68 , considering global emergy transformity to be equal to $15.83 \mathrm{E}+24 \mathrm{seJ} \mathrm{yr}^{-1}$ (Brown and Ulgiati, 2004). The yr - refers to the year considered in the analysis that was 2016 and the values correspond to the conversion factors of the equation.

During the second stage, the emergy table was prepared by entering the numerical value and the units of each flow mentioned in the diagram. The table permits the conversion of all the resources in terms of joules of solar energy, using transformations that allow the emergy indicators to be calculated.

During the final stage of the emergy analysis, the emergy indicators were calculated, with the purpose of evaluating the sustainability of the production systems. Table 2 presents the emergy indicators proposed by Odum (1996), slightly modified as per Ortega et al. (2010) for a more adequate evaluation of resource sustainability, considering the renewability of each of the resources used.

The total emergy, together with the indicators and the ratios calculated with the emergy tables, were used to evaluate the efficiency and environmental impact of the irrigated and rainfed agricultural production systems, in addition to the economic and environmental interactions, and quantification of the sustainability of the Curupati Irrigated Perimeter and the rainfed agriculture.

Table 2. Emergy indicators for the economic, environmental and social evaluation of the irrigated and rainfed production systems.

\begin{tabular}{|c|c|c|}
\hline Indicator & Equation & Description \\
\hline Solar transformity $(\mathrm{Tr})$ & $\mathrm{Y} / \mathrm{E}$ & Ratio of output emergy divided by product energy \\
\hline Renewability (R\%) & $100 x(\mathrm{R}+\mathrm{MR}+\mathrm{SR}) / \mathrm{Y}$ & Ratio of renewable inputs divided by total system emergy \\
\hline Emergy yield ratio (EYR) & $\mathrm{Y} /(\mathrm{MN}+\mathrm{SN})$ or $\mathrm{Y} / \mathrm{F}$ & $\begin{array}{l}\text { Ratio of total used emergy divided by the emergy of non- } \\
\text { renewable inputs from the economy }\end{array}$ \\
\hline Emergy investment ratio (EIR) & $(\mathrm{MN}+\mathrm{SN}) /(\mathrm{R}+\mathrm{MR}+\mathrm{SR}+\mathrm{N})$ or $\mathrm{F} / \mathrm{I}$ & $\begin{array}{l}\text { Emergy ratio between non-renewable inputs from the economy } \\
\text { divided by the investment emergy (natural inputs plus } \\
\text { renewable inputs from the economy) }\end{array}$ \\
\hline Emergy exchange rate (EER) & $\mathrm{Y} /\left[(\$) \times\left(\mathrm{seJ} \${ }^{-1}\right)\right]$ & $\begin{array}{l}\text { The proportion of emergy delivered by the producer to the } \\
\text { economy divided by the emergy received from the buyer }\end{array}$ \\
\hline Environmental load ratio (ELR) & $\mathrm{N}+\mathrm{SN}+\mathrm{MN} / \mathrm{R}+\mathrm{SR}+\mathrm{MR}$ & $\begin{array}{l}\text { The proportion of non-renewable emergy divided by the } \\
\text { renewable input resources }\end{array}$ \\
\hline Emergy sustainability index (ESI) & EYR/ELR & Indicates the sustainability of the production system \\
\hline
\end{tabular}

Source: Ortega et al., 2010, based on Odum, 1996. 


\section{RESULTS AND DISCUSSION}

The systemic diagram of the irrigated and rainfed production systems in the semi-arid region of Brazil is shown in Figure 2, where the different emergy flows that make up the systems and the interactions of their main components can be seen, as well as the different sources of energy from the renewable and non-renewable resources from nature, and resources from the economy, such as services and inputs. Finally, all the input emergy flows from the systems join into a single output flow.

The diagram shows the renewable (sun, rainfall, water resource) and non-renewable resources (soil), besides resources from the economy, such as materials (seedlings, seeds, manure, fertilizers and pesticides) and services (labor, electricity, mechanization and transport), as well as the processes and boundaries of the production systems. The product or output of the production models, as well as the final emergy, consisted of the papaya fruit under the irrigated system, and the sorghum grain under the rainfed system.

The main characteristics of these different resources and their relationships based on emergy, which were used to analyze the behavior of the irrigated production system are described in Table 3. A total emergy of $1.69 \mathrm{E}+17 \mathrm{seJ} \mathrm{ha}^{-1} \mathrm{yr}^{-1}$ was found for the irrigated production system. Of this total, $66.02 \%$ corresponded to resources from the economy, as well as services and materials. The remaining $33.98 \%$ represented renewable and non-renewable environmental resources.

Renewable services accounted for $37.66 \%$ of the total emergy, where family labor was highly significant, accounting for $30.81 \%$, additional labor accounted for $4.11 \%$ and specialized labor, $2.74 \%$. Non-renewable services were equal to $25.66 \%$ of the total emergy, electricity having the greatest contribution with $20.55 \%$, followed by mechanization with $4.67 \%$ and transport with $0.44 \%$. Renewable materials were $2.65 \%$, where the highest percentage corresponded to the fertilizers, the most important being $\mathrm{N}$ with $0.94 \%$. Of the non-renewable materials, only the pesticide was included, equivalent to $0.04 \%$.

For the environmental resources, the highest value was for renewable resources at $33.95 \%$, with the largest contribution from the water resource used for irrigation, corresponding to $33.21 \%$, followed by rainfall with $0.73 \%$. Non-renewable resources were attributed to erosion, equal to $0.03 \%$ of the total emergy.

Figure 2. Systemic diagram of the irrigated and rainfed production models in the semi-arid region of Brazil.

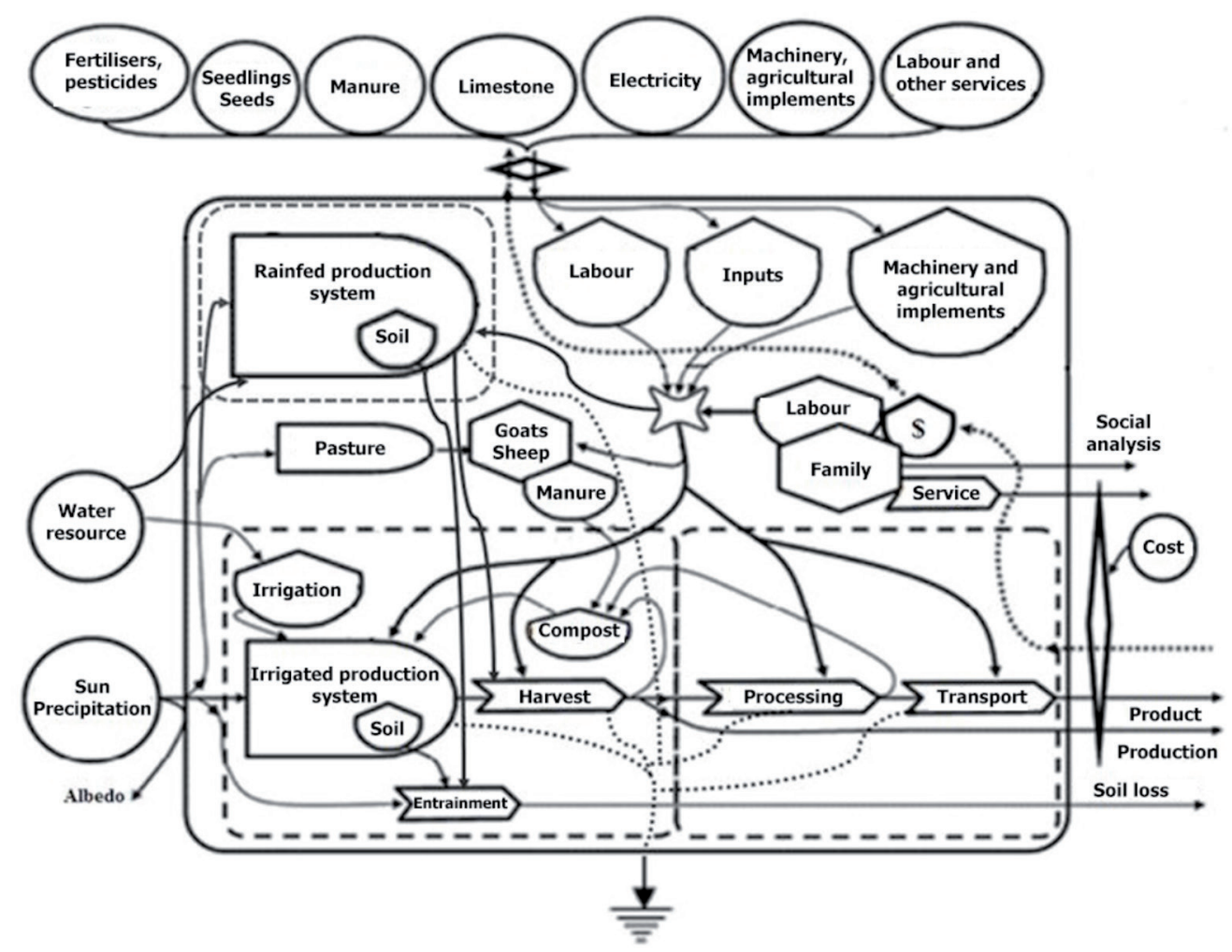


Table 3. Emergy analysis of the production system for irrigated papaya in the semi-arid region of north eastern Brazil.

\begin{tabular}{|c|c|c|c|c|c|c|c|c|c|}
\hline \multirow[b]{2}{*}{ Description } & \multirow[b]{2}{*}{ Value } & \multirow[b]{2}{*}{ Unit } & \multirow[b]{2}{*}{$\mathrm{RF}$} & \multirow[b]{2}{*}{$\operatorname{Tr}$} & \multirow[b]{2}{*}{ Unit } & \multicolumn{3}{|c|}{ Emergy (seJ) } & \multirow[b]{2}{*}{ USD } \\
\hline & & & & & & $\mathrm{R}$ & NR & Total & \\
\hline 1. $\operatorname{Sun}^{(2)}$ & $5.33 \mathrm{E}+10$ & $\mathrm{~J} \mathrm{ha}^{-1} \mathrm{yr}^{-1}$ & 1.0 & $1.00 \mathrm{E}+00$ & $\operatorname{seJ} \mathrm{J}^{-1}$ & $5.33 \mathrm{E}+10$ & $0.00 \mathrm{E}+00$ & $5.33 \mathrm{E}+10$ & 85.18 \\
\hline 2. Precipitation ${ }^{(1)}$ & $4.05 \mathrm{E}+10$ & $\mathrm{~J} \mathrm{ha}^{-1} \mathrm{yr}^{-1}$ & 1.0 & $3.06 \mathrm{E}+04$ & $\operatorname{seJ} \mathrm{J}^{-1}$ & $1.24 \mathrm{E}+15$ & $0.00 \mathrm{E}+00$ & $1.24 \mathrm{E}+15$ & 272.97 \\
\hline 3. Water resource ${ }^{(2)}$ & $1.90 \mathrm{E}+11$ & $\mathrm{~J} \mathrm{ha}^{-1} \mathrm{yr}^{-1}$ & 1.0 & $2.96 \mathrm{E}+05$ & seJ J-1 & $5.62 \mathrm{E}+16$ & $0.00 \mathrm{E}+00$ & $5.62 \mathrm{E}+16$ & 12387.67 \\
\hline \multicolumn{2}{|c|}{ Renewable resources $(\mathrm{R})$} & & & & & $5.75 \mathrm{E}+16$ & $0.00 \mathrm{E}+00$ & $5.75 E+16$ & 12745.82 \\
\hline 4. Erosion ${ }^{(1)}$ & $4.20 \mathrm{E}+08$ & $\mathrm{~J} \mathrm{ha}^{-1} \mathrm{yr}^{-1}$ & 0.0 & $1.24 \mathrm{E}+05$ & $\operatorname{seJ} J^{-1}$ & $0.00 \mathrm{E}+00$ & $5.21 \mathrm{E}+13$ & $5.21 \mathrm{E}+13$ & 11.47 \\
\hline \multicolumn{2}{|c|}{ Non-renewable resources $(\mathrm{N})$} & & & & & $0.00 \mathrm{E}+00$ & $5.21 \mathrm{E}+13$ & $5.21 \mathrm{E}+13$ & 11.47 \\
\hline \multicolumn{2}{|l|}{$\mathrm{I}=\mathrm{R}+\mathrm{N}$} & & & & & $5.75 \mathrm{E}+16$ & $5.21 \mathrm{E}+13$ & $5.75 \mathrm{E}+16$ & 12757.29 \\
\hline \multicolumn{10}{|l|}{ Services $(\mathrm{S})$} \\
\hline 5. Family labor & $2.82 \mathrm{E}+09$ & $\mathrm{~J} \mathrm{ha}^{-1} \mathrm{yr}^{-1}$ & 0.9 & $1.85 \mathrm{E}+07$ & $\operatorname{seJ} \mathrm{J}^{-1}$ & $4.70 \mathrm{E}+16$ & $5.22 \mathrm{E}+15$ & $5.22 \mathrm{E}+16$ & 11491.19 \\
\hline 6. Specialized labor(2) & $2.51 \mathrm{E}+08$ & $\mathrm{~J} \mathrm{ha}^{-1} \mathrm{yr}^{-1}$ & 0.6 & $1.85 \mathrm{E}+07$ & $\operatorname{seJ} \mathrm{J}^{-1}$ & $2.79 \mathrm{E}+15$ & $1.86 \mathrm{E}+15$ & $4.64 \mathrm{E}+15$ & 1022.80 \\
\hline 7. Additional labor ${ }^{(2)}$ & $3.76 \mathrm{E}+08$ & $\mathrm{~J} \mathrm{ha}^{-1} \mathrm{yr}^{-1}$ & 0.6 & $1.85 \mathrm{E}+07$ & $\operatorname{seJ} J^{-1}$ & $4.17 \mathrm{E}+15$ & $2.78 \mathrm{E}+15$ & $6.96 \mathrm{E}+15$ & 1532.16 \\
\hline RS & & & & & & $5.39 \mathrm{E}+16$ & $9.86 \mathrm{E}+15$ & $6.38 \mathrm{E}+16$ & 14046.15 \\
\hline 8. Electricity ${ }^{(1)}$ & $6.17 \mathrm{E}+10$ & $\mathrm{~J} \mathrm{ha}^{-1} \mathrm{yr}^{-1}$ & 0.5 & $5.64 \mathrm{E}+05$ & $\operatorname{seJ} J^{-1}$ & $1.74 \mathrm{E}+16$ & $1.74 \mathrm{E}+16$ & $3.48 \mathrm{E}+16$ & 7664.93 \\
\hline 9. Mechanization & $1.74 \mathrm{E}+03$ & USD & 0.01 & $4.54 \mathrm{E}+12$ & seJ USD ${ }^{-1}$ & $7.92 \mathrm{E}+13$ & $7.84 \mathrm{E}+15$ & $7.92 \mathrm{E}+15$ & 1743.60 \\
\hline 10. Transport & $1.64 \mathrm{E}+02$ & USD & 0.01 & $4.54 \mathrm{E}+12$ & seJ USD ${ }^{-1}$ & $7.42 \mathrm{E}+12$ & $7.35 \mathrm{E}+14$ & $7.42 \mathrm{E}+14$ & 163.50 \\
\hline NS & & & & & & $1.75 \mathrm{E}+16$ & $2.60 \mathrm{E}+16$ & $4.35 \mathrm{E}+16$ & 9572.03 \\
\hline $\mathrm{S}=\mathrm{RS}+\mathrm{NS}$ & & & & & & $7.14 \mathrm{E}+16$ & $3.58 \mathrm{E}+16$ & $1.07 \mathrm{E}+17$ & 23618.18 \\
\hline \multicolumn{10}{|l|}{ Materials (M) } \\
\hline 11. Seedlings & $2.40 \mathrm{E}+02$ & USD & 0.7 & $4.54 \mathrm{E}+12$ & seJ USD ${ }^{-1}$ & $7.64 \mathrm{E}+14$ & $3.27 \mathrm{E}+14$ & $1.09 \mathrm{E}+15$ & 240.40 \\
\hline 12. Manure & $8.08 \mathrm{E}+01$ & USD & 0.6 & $4.54 \mathrm{E}+12$ & seJ USD $^{-1}$ & $2.20 \mathrm{E}+14$ & $1.47 \mathrm{E}+14$ & $3.67 \mathrm{E}+14$ & 80.77 \\
\hline 13. Limestone ${ }^{(3)}$ & $1.00 \mathrm{E}+03$ & $\mathrm{~kg}$ & 1.0 & $1.00 \mathrm{E}+12$ & $\mathrm{seJ} \mathrm{kg-1}$ & $1.00 \mathrm{E}+15$ & $0.00 \mathrm{E}+00$ & $1.00 \mathrm{E}+15$ & 220.26 \\
\hline 14. Nitrogen ${ }^{(1)}$ & $2.50 \mathrm{E}+02$ & $\mathrm{~kg}$ & 1.0 & $6.38 \mathrm{E}+12$ & seJ kg-1 & $1.60 \mathrm{E}+15$ & $0.00 \mathrm{E}+00$ & $1.60 \mathrm{E}+15$ & 351.32 \\
\hline 15. Phosphorus ${ }^{(3)}$ & $2.00 \mathrm{E}+02$ & $\mathrm{~kg}$ & 1.0 & $3.90 \mathrm{E}+09$ & seJ $\mathrm{kg}^{-1}$ & $7.80 \mathrm{E}+11$ & $0.00 \mathrm{E}+00$ & $7.80 \mathrm{E}+11$ & 5.82 \\
\hline 16. Potassium ${ }^{(3)}$ & $2.50 \mathrm{E}+02$ & $\mathrm{~kg}$ & 1.0 & $1.74 \mathrm{E}+12$ & seJ $\mathrm{kg}^{-1}$ & $4.35 \mathrm{E}+14$ & $0.00 \mathrm{E}+00$ & $4.35 \mathrm{E}+14$ & 95.81 \\
\hline RM & & & & & & $4.01 \mathrm{E}+15$ & $4.74 \mathrm{E}+14$ & $4.49 \mathrm{E}+15$ & 994.39 \\
\hline 17. Pesticide ${ }^{(3)}$ & $3.00 \mathrm{E}+00$ & $\mathrm{~kg}$ & 0.05 & $2.49 \mathrm{E}+13$ & $\mathrm{seJ} \mathrm{kg-1}$ & $3.74 \mathrm{E}+12$ & $7.10 \mathrm{E}+13$ & $7.47 \mathrm{E}+13$ & 16.45 \\
\hline NM & & & & & & $3.74 \mathrm{E}+12$ & $7.10 \mathrm{E}+13$ & $7.47 \mathrm{E}+13$ & 16.45 \\
\hline $\mathrm{M}=\mathrm{RM}+\mathrm{NM}$ & & & & & & $4.02 \mathrm{E}+15$ & $5.45 \mathrm{E}+14$ & $4.56 \mathrm{E}+15$ & 1010.85 \\
\hline $\mathrm{F}=\mathrm{M}+\mathrm{S}$ & & & & & & $7.54 \mathrm{E}+16$ & $3.64 \mathrm{E}+16$ & $1.12 \mathrm{E}+17$ & 24629.02 \\
\hline Y. Emergy ${ }^{(4)}$ & & & & & & $1.33 \mathrm{E}+17$ & $3.64 \mathrm{E}+16$ & $1.69 \mathrm{E}+17$ & 37386.31 \\
\hline O. Energy ${ }^{(5)}$ & & & & & & & & $1.63 \mathrm{E}+11$ & \\
\hline
\end{tabular}

RF: renewable fraction; Tr: Solar transformity; I: Natural resources; RS: Renewable services from the economy; NS: Non-renewable services from the economy; S: Services from the economy; RM: Renewable materials from the economy; NM: Non-renewable materials from the economy; M: Materials from the economy; F: Resources from the economy.

${ }^{(1)}$ Brown and Ulgiati (2004); ${ }^{(2)}$ Brown and Ulgiati (2004) and Odum (1996); ${ }^{(3)}$ Odum (1996); ${ }^{(4)}$ Emergy (Y) = I + F; ${ }^{(5)}$ Energy available from the produced food.

Halim (2013) in study impact of alternate furrow irrigation with different irrigation intervals on yield, water use efficiency, and economic return of corn verified alternate-furrow irrigation with appropriate irrigation intervals (7-d) can be used as an efficient method for corn production in arid areas where production depends heavily on irrigation.

It can therefore be seen that family labor especially, was the resource that contributed most significantly to the total emergy of the irrigated production system, in addition to the service of electricity. Ortega et al. (2010), in a study of the emergy of vegetable production systems under organic management, verified that the total emergy of the five systems varied from $1.72 \mathrm{E}+17$ to $6.24 \mathrm{E}+17$ seJ, in which labor contributed most to the total emergy, ranging from $70 \%$ to $90 \%$.

Thus, emergy analysis showed that within a system of agricultural production, resources from the economy were greater; this can be attributed to the need for services at all stages of the production process, in addition to the materials used in each activity.

Giannetti et al. (2011), evaluating the emergy in a coffee plantation in the Brazilian Cerrado, pointed out that services accounted for approximately $29 \%$ of the total emergy, with direct labor alone representing $24 \%$ of this total, and local renewable resources accounting for $20 \%$ of the total emergy in the production of green coffee.

In economic terms, a total value of $37386.31 \mathrm{USD} \mathrm{ha}^{-1} \mathrm{yr}^{-1}$ is seen in the production system for irrigated papaya, with resources from the economy being equivalent to $65.88 \%$ of this total, while environmental resources accounted for $34.12 \%$. Among resources from the economy, services were equivalent to $63.17 \%$, where labor accounted for $37.57 \%$, with the emphasis on family labor at $30.73 \%$. Electricity also had a significant contribution, with $20.50 \%$. 
Ponce et al. (2014) in study economic impacts of climate change on the Chilean agricultural sector observed that although the prodution model accounts for adaptation by allowing for changes in land allocation to cope with climate change, it does not consider other adaptation options, such as the incorporation of different techniques or technologies for farm management.

On the other hand, for the renewable energy resources, the greatest contribution was from the water resource used for irrigation, which corresponded to $33.13 \%$ of the total value of the production system. The production cost of the irrigated papaya, taking the renewable, non-renewable and economic resources together, was USD0.28 $\mathrm{kg}^{-1}$. The greatest contribution to the final value were the costs of services and materials, especially labor and electricity.

For Barros et al. (2009), the high labor costs may explain the dependence of this sector, since in a study of the emergy and economic performance of different systems of banana cultivation in Guadeloupe in the French West Indies, they found that production costs were high, at USD0.60 to USD0.71 $\mathrm{kg}^{-1}$, with on average $48 \%$ of the production costs of each kilogram of bananas attributed to labor.

In relation to the total emergy of the rainfed agricultural production system, Table 4 shows an emergy value of $1.06 \mathrm{E}+16$ seJ ha-1 $\mathrm{yr}^{-1}$, less than in the irrigated system due to the use of less resources from the economy and from the environment.

Resources from the economy also had the greatest contribution $(88.38 \%$ ), of which $85.23 \%$ were services, with the emphasis on family labor (54.38\%) and additional labor (18.07\%); however, non-renewable services, such as transportation and mechanization, accounted for $6.98 \%$ and $5.80 \%$ respectively. Materials accounted for only $3.14 \%$. For the renewable environmental resources, rainfall had the greatest contribution with around $11.35 \%$, while non-renewable resources and erosion were equal to $0.27 \%$.

Barros et al. (2009), in a study of the emergy of different systems of banana cultivation in Guadeloupe, French West Indies, showed that the total emergy was highly dependent on resources from the economy, as they represented between $88 \%$ and $94 \%$. Thus, the main differences between the production systems under study could be seen in the use of the

Table 4. Emergy analysis of the production system for rainfed sorghum in the semi-arid region of northeastern Brazil.

\begin{tabular}{|c|c|c|c|c|c|c|c|c|c|}
\hline \multirow[b]{2}{*}{ Description } & \multirow[b]{2}{*}{ Value } & \multirow[b]{2}{*}{ Unit } & \multirow[b]{2}{*}{$\mathrm{RF}$} & \multirow[b]{2}{*}{$\operatorname{Tr}$} & \multirow[b]{2}{*}{ Unit } & \multicolumn{3}{|c|}{ Emergy (seJ) } & \multirow[b]{2}{*}{ USD } \\
\hline & & & & & & $\mathrm{R}$ & NR & Total & \\
\hline 1. $\operatorname{Sun}^{(2)}$ & $5.24 \mathrm{E}+10$ & $\mathrm{~J} \mathrm{ha}^{-1} \mathrm{yr}^{-1}$ & 1.0 & $1.00 \mathrm{E}+00$ & $\operatorname{seJ} \mathrm{J}^{-1}$ & $5.24 \mathrm{E}+10$ & $0.00 \mathrm{E}+00$ & $5.24 \mathrm{E}+10$ & 86.64 \\
\hline 2. Precipitation ${ }^{(1)}$ & $3.95 \mathrm{E}+10$ & $\mathrm{~J} \mathrm{ha}^{-1} \mathrm{yr}^{-1}$ & 1.0 & $3.06 \mathrm{E}+04$ & $\operatorname{seJ} \mathrm{J}^{-1}$ & $1.21 \mathrm{E}+15$ & $0.00 \mathrm{E}+00$ & $1.21 \mathrm{E}+15$ & 266.23 \\
\hline \multicolumn{6}{|c|}{ Renewable resources $(\mathrm{R})$} & $1.21 \mathrm{E}+15$ & $0.00 \mathrm{E}+00$ & $1.21 \mathrm{E}+15$ & 352.87 \\
\hline 3. Erosion ${ }^{(1)}$ & $2.34 \mathrm{E}+08$ & $\mathrm{~J} \mathrm{ha}^{-1} \mathrm{yr}^{-1}$ & 0.0 & $1.24 \mathrm{E}+05$ & $\operatorname{seJ~J^{-1}}$ & $0.00 \mathrm{E}+00$ & $2.90 \mathrm{E}+13$ & $2.90 \mathrm{E}+13$ & 6.39 \\
\hline \multicolumn{6}{|c|}{ Non-renewable resources $(\mathrm{N})$} & $0.00 \mathrm{E}+00$ & $2.90 \mathrm{E}+13$ & $2.90 \mathrm{E}+13$ & 6.39 \\
\hline \multicolumn{6}{|l|}{$\mathrm{I}=\mathrm{R}+\mathrm{N}$} & $1.21 \mathrm{E}+15$ & $2.90 \mathrm{E}+13$ & $1.24 \mathrm{E}+15$ & 359.27 \\
\hline \multicolumn{10}{|l|}{ Services $(\mathrm{S})$} \\
\hline 4. Family labor ${ }^{(2)}$ & $3.13 \mathrm{E}+08$ & $\mathrm{~J} \mathrm{ha}^{-1} \mathrm{yr}^{-1}$ & 0.9 & $1.85 \mathrm{E}+07$ & $\operatorname{seJ} \mathrm{J}^{-1}$ & $5.21 \mathrm{E}+15$ & $5.79 \mathrm{E}+14$ & $5.79 \mathrm{E}+15$ & 1275.44 \\
\hline 5. Additional labor ${ }^{(2)}$ & $1.04 \mathrm{E}+08$ & $\mathrm{~J} \mathrm{ha}^{-1} \mathrm{yr}^{-1}$ & 0.6 & $1.85 \mathrm{E}+07$ & $\operatorname{se} J^{J^{-1}}$ & $1.15 \mathrm{E}+15$ & $7.70 \mathrm{E}+14$ & $1.92 \mathrm{E}+15$ & 423.79 \\
\hline \multicolumn{6}{|l|}{$\mathrm{RS}$} & $6.37 \mathrm{E}+15$ & $1.35 \mathrm{E}+15$ & $7.71 \mathrm{E}+15$ & 1699.23 \\
\hline 6. Mechanization & $1.36 \mathrm{E}+02$ & USD & 0.01 & $4.54 \mathrm{E}+12$ & seJ USD ${ }^{-1}$ & $6.18 \mathrm{E}+12$ & $6.12 \mathrm{E}+14$ & $6.18 \mathrm{E}+14$ & 136.22 \\
\hline 7. Transport & $1.64 \mathrm{E}+02$ & USD & 0.01 & $4.54 \mathrm{E}+12$ & seJ USD ${ }^{-1}$ & $7.42 \mathrm{E}+12$ & $7.35 \mathrm{E}+14$ & $7.42 \mathrm{E}+14$ & 163.50 \\
\hline \multicolumn{6}{|l|}{$\begin{array}{l}\mathrm{NS} \\
\mathrm{S}=\mathrm{RS}+\mathrm{NS}\end{array}$} & $1.36 \mathrm{E}+13$ & $1.35 \mathrm{E}+15$ & $1.36 \mathrm{E}+15$ & 299.72 \\
\hline $\mathrm{S}=\mathrm{RS}+\mathrm{NS}$ & & & & & & $6.38 \mathrm{E}+15$ & $2.70 \mathrm{E}+15$ & $9.08 \mathrm{E}+15$ & 1998.95 \\
\hline \multicolumn{10}{|l|}{ Materials (M) } \\
\hline \multicolumn{6}{|l|}{ RM (Absent) } & $0.00 \mathrm{E}+00$ & $0.00 \mathrm{E}+00$ & $0.00 \mathrm{E}+00$ & 0.00 \\
\hline 8. Herbicide ${ }^{(3)}$ & $3.00 \mathrm{E}+00$ & $\mathrm{~kg}$ & 0.05 & $2.49 \mathrm{E}+13$ & seJ kg-1 & $3.74 \mathrm{E}+12$ & $7.10 \mathrm{E}+13$ & $7.47 \mathrm{E}+13$ & 16.45 \\
\hline 9. Seeds ${ }^{(4)}$ & $2.92 \mathrm{E}+01$ & USD & 0.23 & $4.54 \mathrm{E}+12$ & seJ USD ${ }^{-1}$ & $3.05 \mathrm{E}+13$ & $1.02 \mathrm{E}+14$ & $1.33 \mathrm{E}+14$ & 29.21 \\
\hline 10. $\mathrm{Bags}^{(5)}$ & $2.80 \mathrm{E}+01$ & USD & 0.10 & $4.54 \mathrm{E}+12$ & seJ USD ${ }^{-1}$ & $1.27 \mathrm{E}+13$ & $1.14 \mathrm{E}+14$ & $1.27 \mathrm{E}+14$ & 28.00 \\
\hline $\mathrm{NM}$ & & & & & & $4.69 \mathrm{E}+13$ & $2.87 \mathrm{E}+14$ & $3.34 \mathrm{E}+14$ & 73.66 \\
\hline $\mathrm{M}=\mathrm{RM}+\mathrm{NM}$ & & & & & & $4.69 \mathrm{E}+13$ & $2.87 \mathrm{E}+14$ & $3.34 \mathrm{E}+14$ & 73.66 \\
\hline $\mathrm{F}=\mathrm{M}+\mathrm{S}$ & & & & & & $6.43 \mathrm{E}+15$ & $2.98 \mathrm{E}+15$ & $9.41 \mathrm{E}+15$ & 2072.61 \\
\hline Y. Emergy ${ }^{(6)}$ & & & & & & $7.64 \mathrm{E}+15$ & $3.01 \mathrm{E}+15$ & $1.06 \mathrm{E}+16$ & 2431.88 \\
\hline O. Energy ${ }^{(7)}$ & & & & & & & & $1.12 \mathrm{E}+10$ & \\
\hline
\end{tabular}

RF: Renewable fraction; Tr: solar transformity; I: natural resources; RS: renewable services from the economy; NS: non-renewable services from the economy; S: Services from the economy; RM: Renewable materials from the economy; NM: Non-renewable materials from the economy; M: Materials from the economy; F: Resources from the economy.

${ }^{(1)}$ Brown and Ulgiati (2004); ${ }^{(2)}$ Brown and Ulgiati (2004) and Odum (1996); ${ }^{(3)}$ Odum (1996); (4) Ortega et al. (2010); (5) Ortega et al. (2010); (6) Emergy $(\mathrm{Y})=\mathrm{I}+\mathrm{F} ;{ }^{(7)}$ Energy available from the produced food. 
more evident resources from the economy, as well as in the renewable resource used for irrigation under the irrigated production system.

In economic terms, the total value was USD2431.88 $\mathrm{ha}^{-1} \mathrm{yr}^{-1}$; once again, resources from the economy exceeded environmental resources, with $85.23 \%$ and $14.77 \%$ respectively. Among the resources from the economy, services accounted for $82.19 \%$, highlighting labor with $69.87 \%$, while materials accounted for only $3.03 \%$. For renewable resources from the environment, the greatest contribution was from precipitation, with $10.95 \%$.

Ponce et al. (2014) in study economic impacts of climate change on the Chilean agricultural sector and a non-linear agricultural supply model observed the Agricultural Supply model is currently not able to analyze this scenario, due to the assumptions about prices and is that the Chilean agricultural sector is vulnerable to the change in agricultural yields as a consequence of climate change.

In general, the contribution of soil erosion as a non-renewable resource was small in both production systems. This was satisfactory for the sustainability of the agricultural systems, since it improves the emergy sustainability index and environmental load ratio, as well as the renewability of the production system. Erosion was considered a non-renewable resource, as the amount of soil lost during the annual cropping cycles cannot be renewed during the crop year; in addition, the period necessary for soil formation and restructuring is very long.

As soil loss depends, among other factors, on the physical properties of the soil, ground cover, etc., the emergy value was higher in the irrigated production system $(5.21 \mathrm{E}+13 \mathrm{seJ})$ than in the rainfed system $(2.90 \mathrm{E}+13 \mathrm{seJ})$. This can mainly be attributed to ground cover and management, since in cultivating the sorghum, planting was by direct sowing, with the soil only being disturbed in the planting row; in the irrigated crop, there was greater soil movement due to the ploughing and harvesting operations, leaving the soil more susceptible to the erosion process.

According to Ghaley and Porter (2013), under conventional production systems, soil exposure leaves the ground susceptible to erosion, compared to integrated systems, which provide ground cover and require relatively few field operations, thereby reducing erosion. The authors found that emergy input due to soil erosion under a conventional

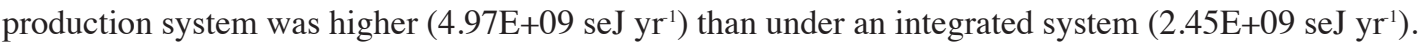

The emergy indices of the production systems are shown in Table 5 , where a greater value for solar transformity can be seen in the irrigated system, of $1040000 \mathrm{seJ}^{-1}$, compared to the rainfed system, of $951000 \mathrm{seJ}^{-1}$. Transformity indicates the efficiency of a system in the production of a product or service. Thus, the lower value found in the rainfed production model indicates greater energy conversion efficiency.

According to Cuvillier (2006), the average values for solar transformity of organic vegetable and conventional production systems were $2.37 \mathrm{E}+05$ and $6.3 \mathrm{E}+06 \mathrm{seJ} \mathrm{J}^{-1}$ respectively. The values found in this study are therefore higher in relation to the organic production systems and lower in relation to the conventional system. For Cuvillier (2006), the main difference is due to variations in the volume of marketed products, as well as the sensitivity of the emergy yield ratio to the amount of available energy being considered.

Renewability establishes the use of renewable resources from nature and the economy as a function of the value for total emergy; it was found that the rainfed system had a greater percentage of renewability (84\%), making it more sustainable in the long term compared to the irrigated system $(74 \%)$. This result is attributed to the greater use of renewable resources from nature and from the economy. Ortega et al. (2010), in studying the emergy of vegetable production systems under organic management, found that the systems under study showed high renewability, ranging from $60 \%$ to $85 \%$.

Table 5. Emergy indicators of the irrigated and rainfed production systems in the semi-arid region of Brazil.

\begin{tabular}{lccc}
\hline Emergy indicators & Unit & Irrigated system & Rainfed system \\
\hline Solar transformity (Tr) & seJ J & 1040000 & 951000 \\
Renewability (R\%) & $\%$ & 74.26 & 83.81 \\
Emergy yield ratio (EYR) & Dimensionless & 1.51 & 1.13 \\
Environmental load ratio (ELR) & Dimensionless & 0.35 & 0.20 \\
Emergy investment ratio (EIR) & Dimensionless & 0.34 & 0.18 \\
Emergy sustainability index (ESI) & Dimensionless & 4.37 & 5.86 \\
Emergy exchange rate (EER) & Dimensionless & 1.00 & 1.00 \\
\hline
\end{tabular}


The emergy yield ratio demonstrates the ability of the system to exploit non-renewable resources from the economy and supply them in the form of products as a response to external investments. It can be seen in Table 5 that the rainfed system shows less potential for socio-economic contribution than the irrigated system, since the EYR of 1.13 indicates that the emergy of the non-renewable resources from the economy is almost equal to the amount of emergy that derives from the final product: the system therefore has little contribution potential for economic growth. The EYR of 1.51 in the irrigated system indicates a slightly better socio-economic contribution. Ortega et al. (2010) found values for the yield ratio in agricultural systems that ranged from 1 to 4 .

According to Brown and Ulgiati (2004), when the EYR is equal to 1, it indicates that the emergy of the local resources is exactly equal to the amount of emergy provided by the economy, therefore the system has no contribution potential for economic growth, being small when $1<\mathrm{EYR}<2$, moderate when $2<\mathrm{EYR}<5$ and high when EYR $>5$.

The values found in this study were similar to those of soybean production systems in Brazil, where the values ranged from 1.18 to 1.78 (Ortega et al., 2005). In a soybean production system in Italy, the yield ratio ranged from 1.98 to 2.32 (Panzieri et al., 2000).

For the environmental load ratio, the value of 0.20 under the rainfed system shows less environmental stress compared to the irrigated system with 0.35 . The higher the value of the ELR, the greater the environmental impact caused by the production system due to the use of non-renewable resources. For Brown and Ulgiati (2004), an ELR $<2$ indicates a low environmental load, $2<$ ELR $<3$, moderately low, $3<$ ELR $<10$ moderate, and ELR $>10$ a high environmental load. The higher value found for the irrigated production model was due to the greater use of non-renewable resources from the economy, especially electricity that corresponded to $20.55 \%$ of the total emergy of the system.

The emergy investment ratio analyses the efficient use of emergy from investments with non-renewable resources from the economy, in relation to renewable resources from nature and the economy, in addition to the non-renewable resources from nature. Thus, the lower value of 0.18 found in the rainfed system means less expenditure of non-renewable emergy, a favorable condition for reducing production costs and providing better market performance, since this indicator is interpreted as a competitiveness index, where a lower EIR means competitiveness of the production system in the market.

The sustainability index evaluates the contribution of system to the economy relative to environmental stress. According to Brown and Ulgiati (2004), an ESI $<1$ indicates an unsustainable system, systems with an ESI $>1$ contribute to economic growth without serious environmental disturbance, intermediate values $(1<\mathrm{ESI}<5)$ characterize medium-term sustainability, and values of ESI $>5$ indicate long-term sustainability. It can thus be seen that the irrigated perimeter has medium-term sustainability due to the greater use of non-renewable resources, whereas the rainfed system has an index of 5.86, indicating long-term sustainability due to the greater use of renewable resources.

For the ratio of product emergy to money emergy, as well as the exchange rate under the two systems, both the producer and the consumer received the same amount of emergy, indicating that neither commercial partner had a relative advantage over the other. When the EER $<1$, the producer has an advantage over the consumer, however, when the EER $>1$, the producer loses emergy and becomes poorer, i.e. the emergy ratio benefits the consumer.

\section{CONCLUSIONS}

We observed the rainfed production system presented a better economic, social and environmental performance compared to the irrigated production system.

The total emergy $\left(1.69 \mathrm{E}+17 \mathrm{seJ} \mathrm{ha}^{-1} \mathrm{yr}^{-1}\right)$ in the irrigated agricultural production system was higher than in the rainfed system $\left(1.06 \mathrm{E}+16 \mathrm{seJ} \mathrm{ha}^{-1} \mathrm{yr}^{-1}\right)$. Therefore, higher energy conversion efficiency in the product chain can be achieved with the rainfed production model, due to the lower emergy input values for production.

The production systems under study contribute to the economic growth of the semi-arid region, with a low environmental load. In addition, the rainfed system presents long-term sustainability, and the irrigated system medium-term sustainability, with values for renewability of $83.81 \%$ and $74.26 \%$, respectively. 


\section{ACKNOWLEDGEMENTS}

The authors acknowledge for financial support and the Coordination for the Improvement of Higher Education Personnel (CAPES) and Cearense Foundation of Scientific and Technological Support (FUNCAP).

\section{REFERENCES}

Agostinho, F., Diniz, G., Siche, R., and Ortega, E. 2008. The use of emergy assessment and the geographical information system in the diagnosis of small family farms in Brazil. Ecological Modelling 210(1-2):37-57.

Barros, I., Blazy, J.M., Rodrigues, G.S., Tournebize, R., and Cinna, J.P. 2009. Emergy evaluation and economic performance of banana cropping systems in Guadeloupe (French West Indies). Agriculture, Ecosystems and Environment 129:437-449.

Brown, M.T., and Ulgiati, S. 2004. Emergy analysis and environmental accounting. Encyclopedia Energy 2:329-354.

Cavalett,O., and Ortega,E. 2009. Emergy, nutrients balance, and economic assessment of soybean production and industrialization in Brazil. Journal of Cleaner Production 17(8):762-771.

Cuvillier, S. 2006. Analysis of methodologies for evaluating the sustainability of agricultural systems. Thesis. Federal University of Rio de Janeiro (UFRJ), Rio de Janeiro, Brazil.

Chen, D., Webber, M., Chen, J., and Luo, Z. 2011 .Emergy evaluation perspectives of an irrigation improvement project proposal in China. Ecological Economics 70:2154-2162.

FAO. 2012. Climate change, water and food security. Food and Agriculture Organization of the United Nations (FAO), Rome, Italy.

Ghaley, B.B., and Porter, J.R. 2013. Emergy synthesis of a combined food and energy production system compared to a conventional wheat (Triticum aestivum) production system. Ecological Indicators 24:534-542.

Giannetti, B.F., Ogura, Y., Bonilla, S.H., and Almeida, C.M.V.B. 2011. Emergy assessment of a coffee farm in Brazilian Cerrado considering in a broad form the environmental services, negative externalities and fair price. Agricultural Systems 104:679-688.

Halim, A. A. 2013. Impact of alternate furrow irrigation with different irrigation intervals on yield, water use efficiency, and economic return of corn. Chilean Journal of Agricultural Research 73:175-180.

INMET. 2017. Climatologia: mapas. Instituto Nacional de Meteorologia (INMET), Brasília D.F., Brasil. Available at http:// www.inmet.gov.br (accessed 14 February 2018).

Lopes, F.B., Souza, F., Andrade, E.M., Meireles, A.C.M., and Caitano, R.F. 2011. Determination of the irrigation management standard practiced in the Irrigated Perimeter Low to Acaraú, Ceará, via multivariate analysis. Irriga Botucatu 16(3):301-316.

Nasuti, S., Eiró, F., and Lindoso, D. 2013. The challenges of agriculture in the Brazilian Semi-arid. Sustainability in Debate 4(2):276-298.

Odum, H.T. 1996. Environmental accounting: emergy and environmental decision making. 370 p. John Wiley, New York, USA.

Ortega, E., Cavalett, O., Bonifacio, R.E., and Watanabe, M. 2005. Brazilian soybean production: Emergy analysis with an expanded scope. Bulletin of Science, Technology and Society 25(4):1-11.

Ortega, E., Guerra, J.G.M., Assis, R.L., e Ribeiro, R.L.D. 2010. Análise emergética de sistemas de produção de olerícolas sob manejo orgânico. Pesquisa Aplicada and Agrotecnologia 3(3):165-182.

Palácio, H.A.Q., Andrade, E.M., Santos, J.C.N., Araújo-Neto, J.R., and Brasil, P.P. 2012. Emergy evaluation of semiarid watersheds under different management strategies. American Society of Agricultural and Biological Engineers 56(6): 1357-1363.

Panzieri, M., Marchettini, N.E., and Hallam, T.G. 2000. Importance of the Bradhyrizobium japonicum symbiosis for the sustainability of a soybean cultivation. Ecological Modelling 135:301-310.

Ponce, R., Blanco, M., and Giupponi, C. 2014. The economic impacts of climate change on the Chilean agricultural sector: a non-linear agricultural supply model. Chilean Journal of Agricultural Research 74:404-412.

Tilman, D., Cassman, K.G., Matson, P.A., Naylor, R., and Polasky, S. 2002. Agricultural sustainability and intensive production practices. Nature 418:671-677.

Venkateswarlu, B., and Prasad, J.V.N.S. 2012. Carrying capacity of Indian agriculture: Issues related to rainfed farming. Current Science 102(6):882-889.

Wang, X., Chen, Y., Sui, P., Gao, W., Qin, F., Zhang, J., et al. 2014. Emergy analysis of grain production systems on large-scale farms in the north China plain based on LCA. Agricultural Systems 128:66-78.

Yi, T., and Xiang, P. 2016. Emergy analysis of paddy farming in Hunan Province, China: A new perspective on sustainable development of agriculture. Journal of Integrative Agriculture 15(10):2426-2436. 